\title{
Cocker Spaniel
}

National Cancer Institute

\section{Source}

National Cancer Institute. Cocker Spaniel. NCI Thesaurus. Code C53882.

The Cocker Spaniel is the smallest member of the Sporting Group. It has a sturdy, compact body and a chiseled head. It has strong, moderately bent, muscular quarters. It is capable of considerable speed, combined with endurance. 